\title{
Effect of Automation of Bond Trading on Bond Market Performance: The Case of Nairobi Securities Exchange
}

\author{
Stephen Mbaya Kimwele*, Mary Bosire, Monica Muiru, Simon Kamau \\ Faculty of Commerce, Department of Accounting, Finance \& Management Science, Egerton University, Nakuru, Kenya \\ Email address: \\ stephenkimwele@yahoo.com (S. Kimwele), bosiremary@yahoo.com (M. Bosire),mshirom@yahoo.com (M. Muiru), \\ Simonms.99@gmail.com (S. Kamau)
}

\section{To cite this article:}

Stephen Mbaya Kimwele, Mary Bosire, Monica Muiru, Simon Kamau. Effect of Automation of Bond Trading on Bond Market Performance: The Case of Nairobi Securities Exchange. International Journal of Economics, Finance and Management Sciences.

Vol. 3, No. 3, 2015, pp. 279-284. doi: 10.11648/j.ijefm.20150303.24

\begin{abstract}
The aim of this study was to investigate the effect of automation of bond trading on the performance of bond market at Nairobi Securities Exchange (NSE). Specifically the study sought to determine the effect of automated bond trading on trading volumes and to determine the effect of automated bond trading on market size. The study adopted a comparative research design and the population of the study comprised of all firms trading on the bond market at the NSE from 2005 to 2012. The data for the study was collected four years before automation and four years after automation. Market capitalization ratio and the number of bonds traded were used to determine pre and post-automation bond market performance. Paired t-test was used to determine whether there was a statistically significant difference between the pre and post automation period. The results of the study indicated that bond trading automation has a positive and a significant effect on the performance of the bond market.
\end{abstract}

Keywords: Automation of Bond Trading, Bond Market Performance, Nairobi Securities Exchange

\section{Introduction}

The vital role played by capital markets all over the globe cannot be overemphasized. A capital market is a major barometer for measuring the aggregate performance of the economy (Nzotta, 2002). Available evidence shows that there is a direct correlation between the level of development of a nation's capital market and her overall social and economic development (Okereke-Onyiuke, 2000). Therefore, there is need for a fast growing capital market, through technological innovation so as to facilitate the speedy growth and development of an economy. Consequently, the use of computer networks has altered the modus operandi of global stock markets. This is characterized by modern innovation and accompanying liberalization of global markets, which have influenced such markets. Older trading systems which rely on personal contact between traders are being replaced by computer networks in which traders throughout the world communicate and trade over microwaves and optical fibers (Wriston, 1999).

The trading system plays an important role in the price discovery process of the market. Recently, many stock exchanges across the world are moving from physical trading platforms to computer based systems. The bulk of evidence points towards improved efficiency after the introduction of automated based trading. Eng and Mak (2003) state that automated trading is the use of electronic platforms for entering trading orders with an algorithm which executes pre-programmed trading instructions whose variables may include timing, price, quantity of the order or in many cases initiating the order by a robot without human intervention. Anthon (2002) adds that algorithmic trading is widely used by investment banks, pension funds, mutual funds, and other buy-side investor-driven institutional traders to divide large trades into several smaller trades in order to manage market impact and risk. On the other hand, sell side traders such as market makers and some hedge fundsprovide liquidity to the market by generating and executing orders automatically.

Computerization of the order flow in financial markets which began in the early 1970 s was designated to provide a 
turnaround system which routed orders electronically to the proper trading post which executed them manually (Alexander at el, 2000). According to Kalumipalli and Warga (2002), financial markets with fully electronic execution and similar electronic communication networks may encourage algorithmic trading by changing the market microstructure thereby permitting smaller differences between the bid and offer prices. This may in turn lead to a decrease in the market-makers' trading advantage, thus increasing market liquidity. Furthermore, the increased market liquidity can make institutional traders to split up orders according to computer algorithms hence they can execute orders at a better average price. These average price benchmarks are measured and calculated by computers by applying the time-weighted average price or more usually by the volume weighted average price (Glosten, 2004).

The introduction of the Central Depository System (CDS) in 2004, the Automated Trading System (ATS) in 2006 and the implementation of Wide Area Network (WAN) in 2007, was the onset for Automation to revolutionize security trading in Kenya. As a result of the automation, the NSE experienced an increase in liquidity while the number of days for settlement and cases of fraud reduced in bond trading as fixed-income traders and investors flocked to the Automated Trading System (ATS). Kariuki (2012) observes that the automation of bond market has enabled investors to see a positive real return on their investments. Cases of fraud have also reduced thereby leading to an increase in investors' confidence. Nonetheless, it is not clear as to whether the automation has an effect on trading volume and market size.

\subsection{Statement of the Problem}

The Nairobi Securities Exchange's secondary bond market came live with the automation of trade in government paper in 2009 and thereafter the automation of other bonds. Most studies done on market performance focus on stock automated trading but not on bond market. Studies have also been carried on the impact of automated systems on efficiency and effectiveness of firms listed. For instance, Kariuki (2012) carried out a study on the impact of automated trading systems (ATS) on Share trading in the Nairobi Stock Exchange while Mailafia (2011) did a study to determine the effect of automation of the trading system in the Nigerian Stock Exchange. While these studies shade some light on the impact of automated system, they do not specifically deal with automated bond trading. The effect of bond trading automation on performance of the bond market is an essential area that requires more attention from researchers since this is expected to spur the bond trading activities. As a result, this study sought to establish whether the automation of bond trading had an effect on the bond market performance in regard to trading volumes and market size.

\subsection{Objectives of the Study}

\subsubsection{General Objective}

This study sought to find out the effects of automation of bond trading on bond market performance at NSE.

\subsubsection{Specific Objectives}

i. To determine the effect of automation of bond trading on trading volumes at the NSE.

ii. To determine the effect of automation of bond trading on market size at the NSE.

\subsection{Research Hypothesis}

$\mathrm{H}_{01}$ : Automation of bond trading has no significant effect on trading volumes at the NSE.

$\mathrm{H}_{02}$ : Automation of bond trading has no significant effect on the growth of market size at the NSE.

\section{Literature Review}

\subsection{Developments in Trading Systems}

Meek at el (1995) contend that the trading floor changed considerably during the more than 400 years of its existence. In trading floor securities were traded with open-outcry, via phone or computer systems. Prices on the floor were fixed by brokers using computer systems. In the recent past, to keep up with speed in trading, brokers used quote machines that issued quotes and were able to fix prices automatically. The development of an electronic market started in the 1990s. For example in Germany, the Integriertes Boersenhandels-und Informations system (IBIS) was launched with a reduced range of shares. Following IBIS was Xetra (Exchange Electronic Trading) in 1997, a computerized trading platform that worked purely on order driven bid and ask limits so as to determine the price of a security when the limits corresponded. The basic targets for these developments were; high liquidity, transparency, location independent market access and frictionless trading (Franke and Hess, 2000).

\subsection{Automation of Bond Trading}

According to Debysingh and Watson (2009), the aim of automating bond trading is to improve both operational and informational efficiency of an exchange. Automated markets provide more efficient discovery of prices because of the lower trading cost, faster execution of trade and better capture of information thereby enhancing efficiency. Brailsford at el (2000) emphasize that automated bond trading system offers greater transparency and dissemination in regard to the quotes and prices of securities. Automated bond trading system exhibit higher feedback on bond trading and provide greater lead time over returns on the securities traded.

\subsection{Bond Market Performance}

Bond automated trading system affects the performance of market in several ways. Brown and Caylor (2006) state 
that the performance of the market can be assessed in relation to the bond trading volumes, market size, reduction in transaction costs and improvements in operational efficiency. According to Oranika (2010), trading volume refers to the quantity of bonds of a given institution traded at specified period of time. Trading volume indicates the trading actions of public buyers and sellers hence it provides information about the activities of the bond traders (Harris, 2003). Conversely, bond market size relates to the amount of bonds outstanding in the market. Downing and Zhang (2004) argue that bond market size changes may be determined by the influence of the automation of bond trading.

Operations efficiency is a market condition that exists when participants can execute transactions and receive services at a price that equates fairly to the actual costs required to provide them (Frame and White, 2004). An operationally-efficient bond market allows investors to make transactions that move the market further toward the overall goal of prudent capital allocation without being chiseled down by excessive frictional costs, which would reduce the risk/reward profile of the transaction (Coelli et al, 2005). On the other hand, transaction costs are the expenses incurred in the process of buying or selling the bonds (Kalimipalli and Warga, 2002). Alexander at el (2000) argues that automated trading systems may provide operationally efficient bond trading market thereby lowering the transaction costs.

\subsection{Theoretical Literature}

According to Edwards at el (2000), the efficient market hypothesis states that asset prices in financial markets should reflect all available information. Consequently, prices should always be consistent with the existing conditions and information in the market. Efficient Stock Markets provide the opportunities for mobilizing savings and investment. They provide opportunities to investors to diversify their portfolios across a variety of assets. In general, ideal market is the one in which prices provide accurate signals for resource allocation so that firms can make productive investment decision and investors can choose among the securities under the assumption that securities prices at any time fully reflect all available information.

The Efficient market Hypothesis identifies three forms of efficiency; weak-form efficiency, semi-strong efficiency and strong-form efficiency. The works of Fama (1970), Samuel and Wilkes (1980), Weston and Copeland (1988), Osaze (2003), Horne (1997) and Scott-Quinn and Deyber (2009) all affirm this position. One medium through which information could be effectively disseminated is the use of computer. Modern technological innovations coupled with globalization have altered the modus operandi of global stock markets. Alile and Anao (1986) argue that a Stock Exchange market flourishes in an environment where the telephone, fax and telex work efficiently. Therefore, a stock exchange will attain a desirable level of efficiency if it is highly automated.

\subsection{Empirical Review}

Mensah and Adom (2012) examined the effect of the automation of Amman stock Exchange (ASE)on the market efficiency using the daily closing price index for a period of 10years . The sample included those stock of the largest and most liquid firms. The results of the study indicated that the shift to electronic trading system increased volatility and had no significant effect on market efficiency. Similarly, Iskandarani and haddad (2012) investigated the impact of applying Electronic Trading System(ETS) on the market liquidity and stock prices behavior In Amman Stock Exchange before and after its implementation using data consisting of closing prices and trading volumes for 38 companies for a period of 8 years. The study employed an event study methodology. Monthly relative means of trading volumes was used as a proxy of measuring liquidity while stock return was used to measure stock price behavior. According to the results of their study, electronic trading has a significant influence on market liquidity.

Al-khouri and Al -Gwazawi (2008) did a study to investigate the impact of the electronic trading system (ATS) on the market volatility and liquidity on the Amman stock Exchange (ASE). The results of their study showed that there was a reduction in volatility and improvement in levels of liquidity after the adoption of electronic trading system at ASE. Furthermore, Marinde (2006) conducted a study on micro structure theoryof the African capital markets in 1999 and discovered that with institutional changes market efficiency and liquidity improved in NSE (Nigerian stock Exchange), NSE (Nairobi stock Exchange), JSE (Johannesburg stock Exchange) while volatility reduced. Mailafia (2011) examined the effect of automation of the trading System in the Nigerian stock Exchange using the key capital market indicators; the market capitalization, turnover by volume, and capitalization. The study results indicated that there was a significant improvement in the performance of these indicators with introduction of the ATS.

Sunday at el (2012) evaluated the effect of the microstructure change (from manual trading system to the automated trading system) on the trading effectiveness in the Nigerian stock market from 1999 to 2011 . The study results revealed that ATS improved the efficiency of the stock market. Additionally, Appiah-Kusi and Menyah (2003) investigated the effects of automation on liquidity and returns of shares in the Tunisian Stock exchange (TSE). The results of the study revealed that automation leads to an increase in liquidity of shares. However, they found that the returns of the shares declined as a result of the automation. Moreover, Ashraf and Joarder (2009) conducted a study to determine the effect of information technology on stock market trade volume and volatility in Dhaka Stock Exchange. According to their results, information technology has a positive and a significant impact on volatility and trading volumes. 


\section{Research Methodology}

\subsection{Research Design and Target Population}

The study adopted a comparative research design. This design was appropriate for the study as it enabled data collection for the pre and post automation period. The study was conducted on all firms trading in the bond market. The study targeted all the 8 firms which were listed and trading bonds between 2005 and 2012 .

\subsection{Data Collection and Analysis}

Pre and post-automation data on market size and number of clients for each corporate bond was collected over the 8 year period. The pre-automation period was taken as the four years (January 2005-December 2008), while the post automation period was taken as four years (January 2009December 2012). Correlation analysis was conducted on the data that was collected in order to determine the degree of relationship between the pre and post-automation bond market performance.

\subsection{Test of Market Size and Trading Volume}

To measure bond market size; Market Capitalization Ratio (MCR) was used. MCR refers to the value of listed corporate bond divided by Gross Domestic product (GDP). Bond market capitalization was computed using the market value of the total bonds. Conversely, the number of bonds traded was used to measure bond trading volume. Two tailed t-test was used to test the significance of the difference in pre and post bond automated trading systems. These tests were hypothesis were conducted at $95 \%$ level of confidence $(\alpha=0.05)$.

\section{Results and Discussion}

\subsection{Descriptive Statistics}

According to the results in table 1 , bond tradingvolumes across the 8 year period had a mean of 16,240,000 while market size as measured by market capitalization ratio had a mean of 40.8665 . There was an increase in trading volumes from $14,310,000,000$ before automation to $18,170,000,000$ after automation. Similarly, the market size of bonds increased by 2.8147 as a result of the automation of bond trading.

Table 1. Descriptive statistics on Trading Volumes and Market size.

\begin{tabular}{llll}
\hline & Pre-automation period & Post-automation period & Mean \\
\hline Trading volumes & $14,310,000,000$ & $18,170,000,000$ & $16,240,000.000$ \\
Market size & 39.4591 & 42.2738 & 40.8665 \\
\hline
\end{tabular}

\subsection{Effect of Automation of Bond Trading on Trading Volumes}

The correlation test results in table 2 indicate that there is a positive and strong correlation between pre-automation and post-automation bond trading volumes. The degree of significance of the relationship was 0.015 . This value was less than 0.05 at $5 \%$ level of significance. This implies that there is a statistical significant difference between post and pre-automation trading volumes. Therefore, this study rejects the null hypothesis and concludes that automation of bond trading has a significant effect on trading volumes at the NSE.

Table 2. Correlation Analysis for the effect of Automation of Bond Trading on Trading Volumes.

\begin{tabular}{lll}
\hline & & Post-automation trading volumes \\
\hline \multirow{2}{*}{ Pre-automation } & Pearson Correlation & $.984^{* *}$ \\
\multirow{2}{*}{ Trading volumes } & Sig. (2-tailed) & .015 \\
\hline
\end{tabular}

\subsection{Effect of Automation of Bond Trading on Market Size}

Table 3. Correlation results for the effect of Automation of Bond Trading on Market Size.

\begin{tabular}{llc}
\hline & & Post-automation Market capitalization/Size \\
\hline Pre-automation & Pearson Correlation & .823 \\
Market capitalization/Size & Sig. (2-tailed) & .014 \\
& $\mathrm{~N}$ & 8 \\
\hline
\end{tabular}

According to the results in table 2, there was a positive relationship between pre and post-automation bond market size as shown by the correlation value of 0.823 . The degree of significance of the relationship between the two periods at $5 \%$ level of significance was $0.014(\mathrm{p}<0.05)$. This indicates that there was a significant difference between pre and post automation market size. Consequently, this study rejects the second null hypothesis and concludes that automation of bond trading has a significant effect on growth of market size at the NSE. 


\section{Summary and Conclusions of the Study}

The aim of the study was to determine the effect of automation of bond trading on bond market performance in Nairobi Securities Exchange. The empirical results of the study showed that trading volumes increased significantly with the bond market automation. The correlation results indicated that there was a positive and a statistically significant relationship between pre and post-automation bond trading volumes. This implies that bond automation has a significant influence on volumes of bonds traded in the bond market. Therefore, increasing the automation efficiency in bond trading will result to increased bond trading volumes in the market. Furthermore, the study results indicated that the market size for bonds increased as a result of the automation. The correlation results between bond trading automation and the bond market size revealed that there is strong positive and a statistically significant relationship between the bond trading automation and the bond market size. This means that bond trading automation has a positive influence on the market size as the changes in market size were higher in the post automation period as compared to the pre-automation period. Therefore, increasing the automation effect will consequently lead to an increase in the size of the bond market.

\section{Suggestions for Future Studies}

Further studies should be conducted to determine the effect of bond trading automation on liquidity as well as on transaction costs. Additionally, studies should be conducted to determine the challenges associated with automated bond trading.

\section{References}

[1] Alexander, G., Edwards, A., \&Ferri, M. (2000). The determinants of trading volume of high-yield corporate bonds, Journal of Financial Markets, 3, 177-204

[2] Alile, E., \&Anao, F.(1986). Financial Theory and Corporate Policy, Addison. Wesley.

[3] Al-Khouri, R.\&Al-Ghazawi, N. (2008). The Effectof Electronic Trading onMarketVolatility and Liquidity inEmerging Markets: Evidence from Amman Stock Exchange. Journal of Derivatives \& Hedge Funds, 14, 222-246.

[4] Anthon, M. (2002). Market Transparency: Who Wins and Who Loses? Review of Financial Studies, 12, 5-35.

[5] Appiah-Kusi, J., \&Menyah, K. (2003). Return Predictability in African Stock Markets. Review of Financial Economics, 12, 247-270.

[6] Ashraf, M., \&Joarder, H.(2008). The Effect of Information Technology on Stock Market Trade Volume and Volatility: A Case of Dhaka Stock Exchange. A.U Journal, 12, 265-270.
[7] Brailsford, T., Faff, R., \& Oliver, B.(2000). An Intracyclical Analysis of the Risk Sensitivity of Bank Stock Returns, Sydney, McGraw-Hill.

[8] Brown, D., and Caylor, L. (2006). Corporate Governance and Firm Valuation. Journal of Accountingand Public Policy, 25, 409-434

[9] Coelli,J., Prasada, R., O’Donnell, C.,\&Battese, G. (2005). An Introduction to Efficiency and Productivity Analysis, New York, Springer.

[10] Debysingh, N., \& Watson, P.(2009). Automation and Efficiency in Two Emerging Equity Markets. Lewis Institute of Social and Economic Studies, 1-17.

[11] Downing, C.,\& Zhang, F.(2004). Trading activity and price volatility in the municipal bond market. Journal of Finance, $59,899-931$.

[12] Edwards,K., Harris, L., \&Piwowar, M.(2004). Corporate Bond Market Transparency and Transaction Costs. Fifteenth Annual Utah Winter Finance Conference.

[13] Eng, L.,\&Mak, Y.(2003). Corporate governance and voluntary disclosure. Journal of Accounting \& Public Policy, 22, 325-345.

[14] Fama, E.(1970). The Behavior of Stock Market Prices. Journal of Business38,34-105.

[15] Frame, K., \& White, T. (2004). Continuous-Time Finance. London: Basil Blackwell.

[16] Franke, G.,\& D. Hess.(2000). Information Diffusion in Electronic and Floor Trading, Journal of Empirical Finance, 7, 455-478.

[17] Glosten, N. (2004). Trading Costs and the Relative Rates of Price Discovery in Stock, Futures, and Option Markets. Journal of Futures Markets, 16, 353-387.

[18] Harris, L.(2003). Trading and Exchanges: Market Microstructure for Practitioners. Oxford, Oxford University Press.

[19] Harris, M.(2003). Differences of Opinion make a Horse Race, Review of Financial Studies, 6, 473- 506

[20] Horne, T. (1997). The Informational Efficiency of the Corporate Bond Market: An Intraday Analysis. Review of Financial Studies, 15, 1325-1354.

[21] Iskandarani, M., \& Haddad, F.(2012). The Effect of Electronic Trading on Market Liquidity and Stock Price Behaviour: An Empirical Study on Ammam Stock Exchange. Jordan Journal of Business administration, 9, 125-150.

[22] Kalimipalli, M., \&Warga, A.(2002). Bid/Ask Spread, Volatility and Volume in the Corporate Bond Market. The Journal of Fixed Income, 11, 31-42.

[23] Kalimipalli, M.,\&Warga, A. (2002). Bid/ask spread, volatility and volume in the corporate bond market. Journal of Fixed Income, 12, 1153-1165.

[24] Kariuki, M. (2012).The impact of automated trading systems (ATS) on Share trading in the Nairobi Stock Exchange. Unpublished MBA Project, University of Nairobi.

[25] Mailafia, H. (2011). The effect of automation of the trading system in the Nigerian Stock Exchange. Journal of Finance, $12,467-482$. 
[26] Marinde, C.(2006) African Stock Market Efficiency and Integration: A study of Eighteen Nations. Journal of Business Finance \& Accounting, 24, 803-814.

[27] Meek G., Roberts C., \& Gray S. J. (1995). Factors Influencing Voluntary Annual Disclosures by U.S., U.K., and Continental European Multinational Corporations. Journal of International Business Studies, 26, 555-572.

[28] Mensah, J., \&Adom, P.(2012). Does Automation Improve Efficiency? Evidence from Amman Stock Exchange.Financial Review, 35, 79-104.

[29] Nzotta, N. (2002). Developments in the Kenyan Domestic Bond Market. 89- 99

[30] Okereke-Onyiuke, J. (2000). Portfolio Selection: Efficient Diversification of Investments. New York: John Wiley \& Sons.

[31] Oranika, P.(2010).Bond Market Trading. Baltimore, Publisha America.
[32] Osaze, P. (2003). Corporate Bond Trading Costs: A Peek behind the Curtain, Journal of Finance, 56, 677-698.

[33] Samuel. L.,\& Wilkes, K.(1980). Security Markets, Information and Liquidity. Financial Markets and Portfolio Management, 3, 67-84.

[34] Scott-Quinn, B., \& Cano, D.(2009). Commercial and Investment Banking and the International Credit and Capital Markets. London, Palgrave Macmillan.

[35] Sunday, J. K., Omah, I.\&Oladimeji, M. (2012). Microstructure Change and the Effective Trading System: The Nigerian Experience. Global Journal of Management and Business Research.12, 10-14.

[36] Weston, O.,\& Copeland, A.(1988). Bond Price Data and Bond Market Liquidity, Journal of Financial and Quantitative Analysis, 24, 367-378.

[37] Wriston, W.(1999). An Empirical Study of Corporate Bond Market Transactions. Financial Analysts Journal, 56, 32-46. 